Dr Rosalind Barber

English \& Comparative Literature

Goldsmiths, University of London

New Cross

London

SE14 6NW

\title{
SHAKESPEARE AND WARWICKSHIRE DIALECT CLAIMS
}

Long-standing claims that Shakespeare used Warwickshire dialect words and phrases have been shown to be false. ${ }^{1}$ Searches of digitized texts on Early English Books Online reveal that most of the words and phrases claimed as Warwickshire dialect were used by Elizabethan and Jacobean writers with no connection to Warwickshire and published in books Shakespeare was likely to have read. The second largest group of words can be characterized as false claims; they either do not appear in the quarto and folio texts (redcoat), or are typographical errors and editorial amendments (hade-land, mobbled, batlet). A smaller group of words arise from the misinterpretation of Shakespeare's poetic inventions, due either to $18^{\text {th }}$ century editors hazarding a guess as to their meaning (honey-stalks) and or to $20^{\text {th }}$ century wishful thinking (golden lads and chimneysweepers $).{ }^{2}$ In two cases, the words are existing verbs that Shakespeare has adapted into adjectives (unwappered, pleached).

In most cases, the classification as Warwickshire dialect has been accepted from Wright's English Dialect Dictionary or earlier dialect glossaries, and passed on by subsequent generations of scholars without scrutiny. The earliest of these, Francis Grose's A Provincial Glossary (1787) was

\footnotetext{
${ }^{1}$ R. Barber, 'Shakespeare and Warwickshire Dialect', Journal of Early Modern Studies (2016), 5: 91-118. Available at: http://www.fupress.net/index.php/bsfm-jems/article/view/18084. Date accessed: 15 June 2018. ${ }^{2}$ R. Barber, 'Shakespeare's "Honey-Stalks", Notes and Queries (2015) 62 (1):92-93 and E. Nelson, 'Shakespeare has missed the dandelion', Shakespeare (2015), 1-10.
} 
not compiled until nearly two centuries after Shakespeare was writing, and nearly two decades after David's Garrick's Shakespeare Jubilee of 1769, meaning that Shakespeare had become an authoritative source. A close examination of these dictionaries and glossaries reveals that the words are usually classified as Warwickshire dialect because of their use by Shakespeare, leading to circular reasoning.

In a recent public debate, Jonathan Bate added four more words to Warwickshire dialect claims, all of which require scrutiny. The claimed dialect words are keech for a cake of wax, cradlecloth for a baby's blanket, dowle for a soft feather and dey for dairy. ${ }^{3}$

The Oxford English Dictionary gives the first published usage of keech to Shakespeare. The definition given is 'A lump of congealed fat; the fat of a slaughtered animal rolled up into a lump. Also dial. with other allied meanings.' Shakespeare uses the word twice. First, it appears as a surname in 2 Henry IV (1600): 'Did not goodwife Keech the butchers wife come in then' (2.1.96). In Henry VIII (1623) it is used to describe Cardinal Wolsey, a butcher's son: 'I wonder, That such a Keech can with his very bulke Take vp the Rayes o' th' beneficiall Sun, And keepe it from the Earth' (1.1.55). Keech is presumably marked as dialect because of Samuel Johnson's note in Plays of Shakespeare (1765, V. 378) 'A keech is a solid lump or mass. A cake of wax or tallow formed into a mould is called yet in some places a keech'; the phrase 'some places' suggesting that 140 years after the First Folio's publication it was used only in certain geographical areas.

But Abraham Veale's An A, B, C for Children, published in London in 1570, features keech in one of its word lists, suggesting it was more widely used in Shakespeare's childhood, and not considered dialect. London-based John Florio was also familiar with keech; it appears in a word list in Florio His Firste Fruites (1578) and is employed as a verb in his A Worlde of Wordes (1598):

\footnotetext{
${ }^{3}$ The debate on $21^{\text {st }}$ September 2017, hosted by the How To: Academy at the Emmanuel Centre in London, can be seen at https://www.youtube.com/watch?v=HgImgdJ5L6o. Starting at 78.36, Jonathan Bate says: 'And then also this - that the local dialect in [...] manuscript inventories of people from Stratford-upon-Avon a cake of wax is called a "keech". Shakespeare uses that word. There's a distinctive term called "cradlecloth" in which to wrap an infant, Shakespeare uses that word. "Down", a soft feather, is "dowle" rather than "down". Shakespeare uses "dowle". "Dairy" is "dey". Shakespeare uses that word.'
} 
'Pozzaria, a kinde of earthen pot, pitcher, or bucket to drawe or keech water with'; 'Scodellare, to dish, to keech vp, or put into dishes, either meate or potage.' The $O E D$ doesn't have a separate entry for keech as a verb, though it does say 'Some modern dialects (Wilts, Hants) have a verb keech to congeal, consolidate (as fat)'. Florio's verb use suggests the word was used to mean 'serving' ('keech up'). Its application to serving water does not marry with Samuel Johnson's 'solid lump or mass', and allows keech to pertain to provisions other than meat, while retaining the sense of portioning. The history of keech as reflected in these records suggests that its wider definition and use was reduced over the next century and a half, but it does not support the idea that Shakespeare was using a word his audience would have considered dialect. In most other records on Early English Books Online it is found as a surname, as in 2 Henry IV.

Dowle (a soft feather) is another word used by writers not associated with Warwickshire, and was clearly not dialect at the time, even if it became so. In The Tempest, Shakespeare refers to 'One dowle that's in my plumbe [plume]' (3.3.65). The Oxford English Dictionary's entry for dowl gives an early use in The Ploughman's Tale (c.1535): 'The Gryffon..swore by cockes herte blode / He wolde hym tere euery doule' (iii. sig D.iii). Perhaps more critically, a search of Early English Books Online finds 'dowle' in Arthur Golding’s 1567 translation of Ovid's Metamorphosis, a wellknown Shakespeare's source: 'There is a groue of Myrtle trees with frute of dowle colour'. ${ }^{4}$ Oxford alumnus and declared London resident Timothy Kendall also used dowle in his 1577 translation of Martial's epigram 'To Cherimon': 'Well goe to: if vpon a bed of dowle thou shouldest lye'. ${ }^{5}$ It is clear that the word was not confined to Warwickshire and would have been known to Shakespeare from printed sources. Two mentions of dowle in the 17 th century factual account Humane Industry (1661) also suggests a once general rather than regional use.

\footnotetext{
${ }^{4}$ A. Golding, The. xv. bookes of P. Ouidius Naso, entytuled Metamorphosis (1567), 139r. Myrtle berries, though more often blue, can indeed be the yellow-white colour associated with down (i.e. dowle).

${ }^{5}$ T. Kendall, Flovvers of epigrammes, out of sundrie the moste singular authours selected, as well auncient as late writers. Pleasant and profitable to the expert readers of quicke capacitie: by Timothe Kendall, late of the Vniuersitie of Oxford: now student of Staple Inne in London (1577), sig Ciiiv.
} 
Cradlecloth falls into the category of false claims. The term Shakespeare uses is 'cradle clothes'. The line in 1 Henry IV is 'That some night tripping fairy had exchang'd, / In cradle clothes our children where they lay.' (1.1.87). In all six quartos from 1598 to 1622 , and in the 1623 Folio versions, Shakespeare uses 'cradle clothes' (with or without a hyphen, sometimes with the first word capitalized). Cradle clothes are, rather obviously, clothes that babies wear when in their cradles: an iambic-friendly phrase for infant sleepwear. Whether the hyphenated or unhyphenated version is preferred by the author we cannot tell. But there is nothing specific to Warwickshire about the concept, nor about the two words 'cradle' and 'clothes', either separately or in combination.

Dey is, strictly speaking, another false claim, if a long-established one. Neither the 1598 and 1631 quartos of Love's Labour's Lost, nor the 1623 Folio text, use the word dey: 'this Damsell, must keepe her at the Parke, shee is alowd for the Day-woman' (1.2.428). Jonathan Bate takes his claim from Hilda Hulme who in Explorations in Shakespeare's Language says 'The dey house in Stratford is the dairy' (331), and follows the lead of previous editors that 'dey-woman' is Shakespeare's intention. But even if we allow that 'day' and 'dey' are interchangeable, and that 'dairy-woman' is the true meaning of 'day-woman', the word dey for dairy cannot be claimed for Warwickshire. Dey as a word for dairy is from Old Norse, via Old English, and was clearly at one time used across the British Isles. The $O E D$ gives nine uses of dey, four uses of dey-house, and three uses of dey-wife (all with various spellings) before 1598. Three hundred years after Love's Labour's Lost was published, dey had, according to Joseph Wright, dwindled to dialect use in a few regions. These included Worcestershire, Herefordshire, Gloucestershire (at least reasonably close to Warwickshire), but also Suffolk, Hampshire, Wiltshire and Scotland. ${ }^{6}$ But this (reasonably wide) dialectical use is no indication of its use in Shakespeare's time. The $O E D$ notes an early use of dey

\footnotetext{
${ }^{6} \mathrm{~J}$. Wright, The English dialect dictionary : being the complete vocabulary of all dialect words still in use or known to have been used during the last 200 years (1898), available at https://archive.org/stream/englishdialectdi02wrig\#page/64/mode/2up/search/dey. Date accessed: 26 June 2018.
} 
by Londoner Geoffrey Chaucer, not only suggesting that the word was (in the $15^{\text {th }}$ century at least) known to those raised in urban settings, but clearly making it accessible, in text form, to Shakespeare and his contemporaries. But Shakespeare may not have intended his 'day-woman' to mean 'dairy-woman' in any case. The $O E D$ 's definition for dey allows that it may be used 'with the more general sense, female servant, maid-servant'. And since Shakespeare's woman is a not spelt 'dey-woman' but 'day-woman' (capitalised only in the Folio text) then a general servant (the kind that comes for the day, rather than living-in) may be all that's intended.

To summarise these findings, keech (used by Florio), dowle (used in Golding's translation of Ovid) and dey (used by Chaucer) seem to have been known in London and other places in the British Isles, as well as being used by writers Shakespeare is likely to have read. Neither dey nor cradlecloth were actually used by Shakespeare (or even intended, as far as we can tell), and the words he did use ('day', 'cradle clothes') are not dialect words.

Though scholars might be tempted to add further words and phrases to the list of supposed 'Warwickshire dialect' words in Shakespeare's canon, they should be wary of doing so. We have no dialect dictionaries compiled during the era, and language use changes significantly over time, with some once widespread words dwindling until they exist only in geographical pockets (as 'dialect') but their use is rarely so narrow as to be pinpointed to a single area. David Crystal confirmed to me that when compiling Shakespeare's Words (2002), he explored claims that Shakespeare had used Warwickshire dialect words and 'concluded that they were baseless and not worth a listing.'7

\section{ROSALIND BARBER}

Goldsmiths, University of London.

\footnotetext{
${ }^{7}$ Personal correspondence with David Crystal, 23 March 2016.
} 